\title{
Workplace health and the garment sector in Cambodia
}

Bunmey Yat

Carolyn Rodehau

Population Council

David Wofford

Population Council

Ashish Bajracharya

Population Council

Follow this and additional works at: https://knowledgecommons.popcouncil.org/departments_sbsr-rh

Part of the Demography, Population, and Ecology Commons, Family, Life Course, and Society Commons, International and Comparative Labor Relations Commons, International Public Health Commons, and the Women's Health Commons How does access to this work benefit you? Let us know!

\section{Recommended Citation}

Yat, Bunmey, Carolyn Rodehau, David Wofford, and Ashish Bajracharya. 2017. "Workplace health and the garment sector in Cambodia," Policy brief. Washington DC and Phnom Penh: Population Council, The Evidence Project.

This Brief is brought to you for free and open access by the Population Council. 


\section{INTRODUCTION}

This policy brief presents selected findings from a stakeholder and situational analysis of women's health in the context of garment factories in Cambodia, carried out by the Cambodia Worker Heath Coalition (WorkerHealth) under the Evidence Project, with financial support of USAID/Cambodia. The objectives of the stakeholder and situational analysis were to: 1) identify key relevant stakeholders and understand their technical expertise, focus areas, and experience in workplace activities and policy change; 2) understand organizational relationships among the stakeholders identified; and 3) determine opportunities and strategies for working collaboratively to improve worker health and support systemic and scaleable improvements.

Ultimately, this policy brief is meant to be a resource for efforts to improve the health and well-being of female garment workers.

\section{METHODS}

The stakeholder mapping and situational analysis included:

- A desk review of organizational websites, activities and activity reports

- One-on-one interviews with organizations

- Synthesis of initial and ongoing organizational outreach by WorkerHealth

- Background research on the industry, including studies on competitiveness, factory compliance with labor standards, worker buying behaviors, labor disputes and work health issues

\section{OVERVIEW OF INDUSTRY ISSUES \& POLICY LANDSCAPE}

The starting point for any analysis of the Cambodia garment industry is its size, composition, and economic importance. An estimated 700,000 workers, predominantly young women from rural areas, are employed in garment factories. The industry produces more than 80 percent of the country's exports and accounts for $\$ 5$ billion in revenue. Its economic importance makes it the focal point for discussions and policy changes that have national reverberations.

There are many industry and labor issues that occupy industry stakeholders, both international and national, and shape the policy environment and landscape for collaboration and engagement on worker health. This analysis does not address those issues, and instead focus on those that relate directly to health.

Occupation Safety and Health (OHS) is a major area of industry focus. Better Factories Cambodia (BFC) monitors OHS compliance across approximately 500 factories with almost 500,000 workers. Compliance has been an ongoing concern, but BFC did find improvements in posting of health policies and stocking of first aid kits. Building and fire safety are important safety foci. Although Cambodia has not seen tragic events like those in Bangladesh in 2013, there are heightened concerns about building and fire safety. Additionally, there are safety concerns for workers who ride crowed buses and trucks to and from the factories, as traffic accidents have led to injury and death.

The health issue that has received the most attention nationally and internationally is worker fainting. There is no agreement about the causes of fainting: some point to lifestyle choices of workers (e.g. staying out late) and others to workers' inability to access nutritious food. For brands, addressing fainting is a major reputation issue, as fainting is increasingly seen by the international community as a sign of poor worker treatment.

Two recent and important health policy changes are relevant to the industry. The first and most significant change for garment workers and factory owners is the new health insurance scheme of the National Social Security Fund (NSSF), which is under the purview of MoLVT. The Sub-decree establishing the scheme was approved by the Prime Minister in January 2016, and the Prakas (regulation) on the health care scheme was released in March 2016. The program will initially target 100,000 workers in and around Phnom Penh and Kandal. A major extension of health services to workers, the scheme is part of the government's long-term plan to provide universal health services to all Cambodians.

The second health policy change being considered, which will indirectly affect industry, addresses regulations governing the licensure and registration of doctors, nurses, midwives, dentists and pharmacists. Under the proposed law, these health providers - regardless of whether they work in a private clinic, in a factory, or public facility - will be required for the first time to register with their respective professional council or face monetary penalties. This change will affect the garment industry because factory health providers will be expected to comply, and there will be questions regarding the role factory management, buyers, and industry groups should play in ensuring that compliance.

The garment industry exists in a complex and challenging policy environment. Advancing policies and practices to improve female garment worker health requires identifying the key stakeholders, opportunities for coordinated action and strategies for engaging influential stakeholders. 


\section{FINDINGS}

The analysis reviewed 30 organizations, including 4 government ministries/national institutions, 8 international agencies and donors, 3 industry organizations, 11 NGOs, and 4 labor-related organizations. It makes no claims to being exhaustive, nor suggests that these organizations are the only ones of importance.

The organizations identified were based on criteria related to the intersections between worker health, including reproductive health and family planning, and industry. We refer these organizations as "stakeholders."
These stakeholders were organized into five broad categories:

- Government agencies/National institutions

- International donors and agencies

- Industry organizations

- Non-governmental organizations

- Labor-related organizations

Table 1 provides a list of each of the stakeholders identified.

TABLE 1. STAKEHOLDERS IDENTIFIED AND INTERVIEWED

\begin{tabular}{|c|c|c|c|}
\hline TYPE OF STAKEHOLDER & STAKEHOLDER & DESK REVIEW & INTERVIEW \\
\hline \multirow{4}{*}{$\begin{array}{l}\text { Government agencies/ } \\
\text { National institutions }\end{array}$} & Ministry of Labour and Vocational Training (MoLVT) & $\mathrm{x}$ & $x$ \\
\hline & Ministry of Health $(\mathrm{MoH})$ & $x$ & \\
\hline & Ministry of Women's Affairs & $x$ & \\
\hline & Arbitration Council & $x$ & \\
\hline \multirow{8}{*}{$\begin{array}{l}\text { International donors } \\
\text { and agencies }\end{array}$} & United Nations Population Fund (UNFPA) & $x$ & \\
\hline & United States Agency for International Development (USAID) & $x$ & $x$ \\
\hline & Department of Foreign Affairs and Trade (DFAT) & $x$ & $x$ \\
\hline & German International Cooperation Agency (GIZ) & $x$ & $x$ \\
\hline & Agence Française de Développement (AFD) & $x$ & $x$ \\
\hline & International Labour Organization & $x$ & $x$ \\
\hline & World Bank/International Finance Corporation & $x$ & \\
\hline & UN Women & $x$ & \\
\hline \multirow{3}{*}{ Industry organizations } & Garment Manufacturing Association of Cambodia (GMAC) & $x$ & $x$ \\
\hline & $\begin{array}{l}\text { Cambodian Federation of Employers and Business Associa- } \\
\text { tions (CAMFEBA) }\end{array}$ & $x$ & $x$ \\
\hline & Multiple Brands & $x$ & $x$ \\
\hline \multirow{11}{*}{ NGOs } & Marie Stopes International Cambodia & $x$ & $x$ \\
\hline & Reproductive Health Association of Cambodia (RHAC) & $x$ & $x$ \\
\hline & CARE & $x$ & $x$ \\
\hline & Save the Children & $x$ & $x$ \\
\hline & The Population Council & $x$ & \\
\hline & University Research Company (URC) & $x$ & $x$ \\
\hline & Population Services International (PSI) & $x$ & \\
\hline & Business for Social Responsibility (BSR)/HERproject & $x$ & $x$ \\
\hline & Oxfam Belgium & $x$ & $x$ \\
\hline & Groupe de Recherches et d'Echange Technologiques (GRET) & $x$ & $x$ \\
\hline & Enfants \& Développement (E\&D) & $x$ & \\
\hline \multirow{4}{*}{$\begin{array}{l}\text { Labor-related } \\
\text { organizations }\end{array}$} & Better Factories Cambodia (ILO/BFC) & $x$ & \\
\hline & Cambodia Labour Confederation (CLC) & $x$ & $x$ \\
\hline & American Center for International Labor Solidarity, AFL-CIO & $x$ & $x$ \\
\hline & Arbitration Council Foundation (ACF) & $x$ & $x$ \\
\hline
\end{tabular}




\section{A. STAKEHOLDER PROGRAMS}

For a comprehensive review and analysis of workplace programs, please see the report Garment Sector Health Interventions in Cambodia: A Comprehensive Review That comprehensive review found that garment factory-based interventions have been led by a variety of organizations, with different sources of funding, including the United States Agency for International Development (USAID), The Australian Department of Foreign Affairs and Trade (DFAT), Agence Française de Développement (AFD) and brands. Interventions were mostly led by a single organization, though joint partnership models are emerging. Projects are predominately located in Phnom Penh and Kandal and implemented in factory compounds, though increasingly expanding beyond the factory setting. Each intervention took place at fewer than 20 factories and reached fewer than 25,000 workers.

\section{B. POLICY ENVIRONMENT \& ENGAGEMENT}

\section{Policy Environment}

The policy environments for health and for industry in general involve many stakeholders and considerable activity around a variety of issues. Some policy issues are directly related to worker health, such as fire and building safety or worker nutrition and fainting, while others are indirectly related, including labor disputes related to cost of living expenses or family leave policies at the workplace. Worker health issues, and particularly worker reproductive health, tend to be overshadowed by industry focus on labor stability, trade union regulation, minimum wage levels, labor contracts, and overall productivity.

There are three policy areas with significant relevance to worker health and the workplace in which key stakeholders are involved:

- Health Insurance/Health System Strengthening

- Occupational Safety \& Health/Workplace Regulation

- Sexual Harassment and Violence

Table 2 highlights relevant policy developments in these areas and the organizations involved in their development.

\section{Degree of Engagement in Policy Development}

Stakeholder influence on policy development is related to their level of engagement with policy makers. Government ministries and the national legislature set policy and define regulations, although certain ministries have more influence than others, depending on the policies under consideration and their jurisdiction. Non-governmental stakeholders have influence if they have access to give policy makers direct input and if policy makers consider their input important.

The matrix below (Figure 1) categorizes a subset of key stakeholders reviewed into quadrants that map their policy "influence" against their level of policy interest in worker health.

FIGURE 1. INTEREST AND POWER DYNAMICS OF STAKEHOLDERS

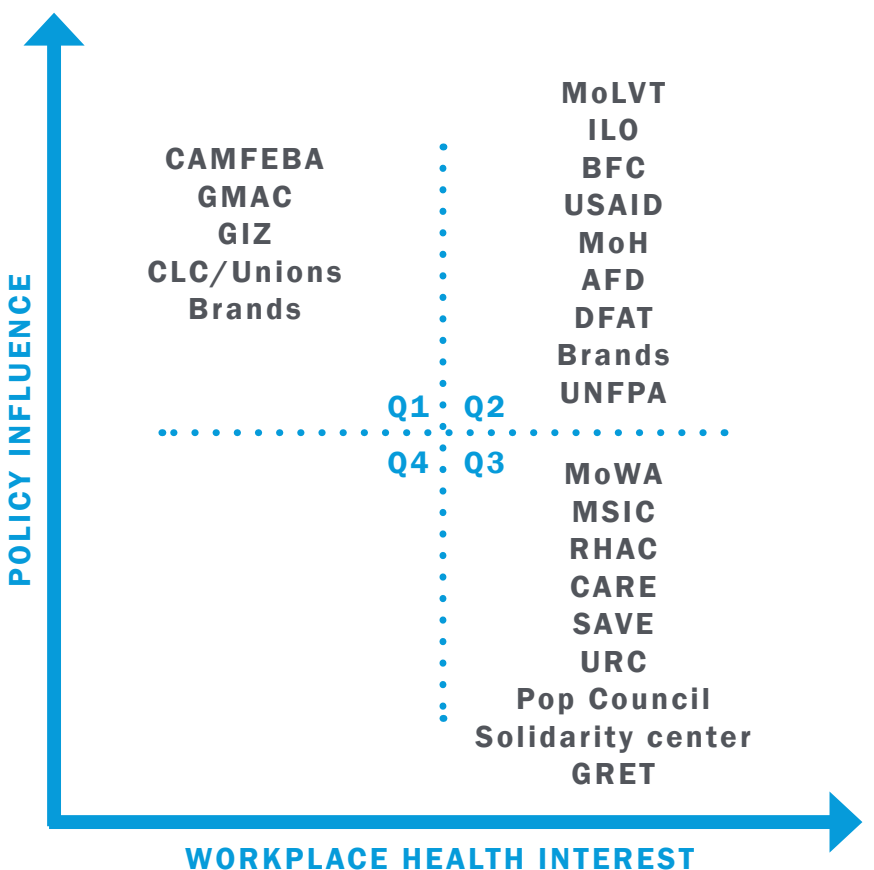

This analysis examined policy interest and influence related specifically to worker health and workplace regulation. It focused narrowly on ministries with direct jurisdiction over health and women's issues, that is, MoLVT, MoH, and MoWA. MoLVT regulates the garment industry and shapes workplace occupational safety and health policies, and consequently it has the greatest influence on policies related to labor and worker health. Other ministries such as Commerce and Finance were not included but are highly important actors in government policy processes.

This categorization provides a very general representation of the influence on and comparative interest in policy to improve worker health. "Low interest" does not indicate a lack of concern for worker health, only generally where worker health stands in relation to their overall interests and institutional priorities.

Each quadrant requires a strategy for building collaboration. Quadrant 1 largely comprised labor and industry groups, including some brands, that have had relatively limited interest in policies expanding worker health services or access, although they are very engaged in policies affecting workers and factories, including safety and health. 


\section{TABLE 2. POLICY DEVELOPMENTS}

\section{POLICY
DEVELOPIMENT}

\begin{tabular}{|c|c|}
\hline $\begin{array}{l}\text { The National Social } \\
\text { Security Fund (NSSF) } \\
\text { Health Insurance } \\
\text { Scheme } \\
\text { Under development }\end{array}$ & $\begin{array}{l}\text { - The health insurance scheme will cover all formal workers and provide services for a } \\
\text { wide range of worker health needs, including family planning, through public health } \\
\text { facilities and, eventually, accredited private facilities. } \\
\text { - Employers and workers will contribute equally to the health insurance, at } 1.3 \% \text { per worker. } \\
\text { - The scheme began in May } 2016 \text {, focused initially on factories that participated in } \\
\text { the Health Insurance Project. It has expanded to other factories located in Phnom } \\
\text { Penh, Kandal, and Kampong Speu provinces, reaching } 100,000 \text { workers, and will be } \\
\text { expanded to other provinces. }\end{array}$ \\
\hline $\begin{array}{l}\text { Revision of regulations } \\
\text { that govern health pro- } \\
\text { fessionals } \\
\text { Under development }\end{array}$ & $\begin{array}{l}\text { - The MoH is revising the regulations governing the registration and licensing of health } \\
\text { professionals (doctors, nurses, nurse-midwives, pharmacists and dentists) and revis- } \\
\text { ing the mandate of their professional councils. } \\
\text { - Under the proposed framework, all health professionals, whether they work in a pub- } \\
\text { lic health center, private facility or a factory, must register with professional councils } \\
\text { and go through new licensing requirements. } \\
\text { - The draft regulations, which are expected to go to the National Assembly in mid- to } \\
\text { late } 2016 \text {, include penalties for failure to register with one's professional council. } \\
\text { - This law builds on the Health Profession Councils' National Strategic Plan } 2015-2020 \\
\text { for strengthening health regulation and improving quality assurance for public and } \\
\text { private health providers. }\end{array}$ \\
\hline $\begin{array}{l}\text { Updates and strategies } \\
\text { for public health facility } \\
\text { improvements } \\
\text { Under development }\end{array}$ & $\begin{array}{l}\text { - The MoH oversees the development of policies and strategies to improve public } \\
\text { health services, in particular, the Minimum Package of Activities (MPA), the Health } \\
\text { Strategic Plan, and the National Strategy for Reproductive and Sexual Health, } \\
\text { - The MPA applies to health centersand includes health promotion, outreach activities, } \\
\text { reproductive and maternal and child health services, family planning, vaccination, } \\
\text { minor surgery, adolescent and youth friendly services and Violence Against Women. } \\
\text { - The Health Strategic Plan (2016 - 2020) provides guidance to health institutions on } \\
\text { effective use of their available resources to achieve national health goals. } \\
\text { - The National Strategy for Reproductive and Sexual Health (2017-2020), still being } \\
\text { developed, is to create a coordinated response to Cambodia's reproductive and sexual } \\
\text { health needs and mobilize the resources necessary for effective action, including } \\
\text { through multi-sectoral partnerships. }\end{array}$ \\
\hline
\end{tabular}

Occupational Health/Workplace Health Regulation

\begin{tabular}{|l|l|l}
\hline $\begin{array}{l}\text { Revision of Prakas and } \\
\text { national guidelines for } \\
\text { enterprise infirmary } \\
\text { services } \\
\text { Under development }\end{array}$ & $\begin{array}{l}\text { - The MoLVT, through its internal HIV/AIDS Committee, launched a process in Decem- } \\
\text { ber 2015 to consider developing national guidelines for infirmaries. }\end{array}$ \\
\hline $\begin{array}{l}\text { OSH standards for enter- } \\
\text { secretariat. }\end{array}$ & $\begin{array}{l}\text { - New regulations and the development of occupational health and safety guidelines } \\
\text { for entertainment workers. }\end{array}$ \\
\hline Launched 2014 & $\begin{array}{l}\text { The development of these standards involved extensive tripartite negotiations, with } \\
\text { participation from non-governmental organizations and facilitation by the ILO. }\end{array}$
\end{tabular}

Sexual Harassment and Violence

\begin{tabular}{|l|}
\hline Cambodia's 2nd Na- \\
tional Action Plan for \\
Violence Against Women \\
$(\mathbf{2 0 1 4 - 2 0 1 8 )}$ \\
Completed in 2015 \\
\hline National Guidelines \\
for Managing Violence \\
Against Women \\
Clinical Handbook for \\
Managing Violence \\
Against Women
\end{tabular}

- DFAT provided funding for the Ministry of Women's Affairs to develop and implement this national action plan, with the support from UN Women and other development partners.

- It identifies three priority areas; domestic violence, rape and sexual violence, and violence against women with increased risk.

- UNFPA provided technical and financial support to $\mathrm{MoH}$ to develop and implement these guidelines.

- The guidelines focus mainly on policy, knowledge management and advocacy activities to improve policy planning and services to women and children who are victims of violence.

- The Handbook focuses on skills and services that health care providers and health system should provide and support the victims of violence.
MoLVT, MEF

$\mathrm{MoH}$

$\mathrm{MoH}$

UNFPA, USAID,

WorkerHealth

(Population Council and Marie Stopes),

PSL (CARE, Save

the Children, MSIC), RHAC, ILO BFC

MoLVT, CARE, ILO

MOWA, UNFPA, DFAT,UN Women, , WHO, GIZ, CARE

UNFPA, WHO, UN Women, GIZ and CARE 


\section{Sexual Harassment/Violence Against Women}

These issues are central elements in efforts to promote women's empowerment and, given the composition of the workforce, are an industry concern. A range of stakeholders, including UNFPA, UNWomen and CARE in coordination with Ministry of Women's Affairs (MoWA) are addressing violence and sexual harassment.

\section{CONSULTATIVE MECHANISMS}

Each of the issue areas mentioned above has some form of existing convening or collaborative mechanism, some of which may offer opportunities for policy dialogue as cooperation on female workers' reproductive health and general health needs. These and other convening spaces can be leveraged to influence policy dialogue, share experiences, and disseminate knowledge and information. It makes strategic and practical sense to limit the number of new demands on stakeholders' time and resources to foster collaboration.

Table 3 lists the consultative mechanisms that may be leveraged for worker health dialogue.

TABLE 3. CONSULTATIVE MECHANISMS

\begin{tabular}{|c|c|c|c|c|c|}
\hline MECHANISM & $\begin{array}{l}\text { ISSUE AREA/ } \\
\text { TOPIC }\end{array}$ & $\begin{array}{l}\text { LED/ } \\
\text { CHAIRED BY }\end{array}$ & PURPOSE & PARTICIPANTS & FREQUENCY \\
\hline $\begin{array}{l}\text { Labour Advisory } \\
\text { Committee (LAC) }\end{array}$ & Minimum wage & $\begin{array}{l}\text { Ministry of Labour } \\
\text { and Vocational } \\
\text { Training }\end{array}$ & $\begin{array}{l}\text { LAC is a main tripar- } \\
\text { tite body that meets } \\
\text { mainly to discuss } \\
\text { issues related to min- } \\
\text { imum wage setting in } \\
\text { the garment sector. }\end{array}$ & $\begin{array}{l}28 \text { members: } 14 \text { from } \\
\text { government, } 7 \text { from } \\
\text { employers, and } 7 \text { from } \\
\text { unions. }\end{array}$ & Annual \\
\hline $\begin{array}{l}\text { Strengthening } \\
\text { Activities for Factory } \\
\text { Education (SAFE) }\end{array}$ & $\begin{array}{l}\text { HIV/AIDS Occupa- } \\
\text { tional Safety and } \\
\text { Health Sexual } \\
\text { harassment }\end{array}$ & $\begin{array}{l}\text { GMAC's Opera- } \\
\text { tions Manager \& } \\
\text { CARE }\end{array}$ & $\begin{array}{l}\text { Share updates on } \\
\text { new relevant policies } \\
\text { or training related to } \\
\text { sexual harassment, } \\
\text { HIV/AIDS, OSH. }\end{array}$ & $\begin{array}{l}45 \text { factories' Human } \\
\text { Resource and Manage- } \\
\text { ment staff, Represen- } \\
\text { tative from MoLVT and } \\
\text { GMAC }\end{array}$ & \\
\hline Buyer Forum & $\begin{array}{l}\text { ILO Better Work } \\
\text { Programme } \\
\text { issues (labor } \\
\text { compliance, } \\
\text { advisory services, } \\
\text { governances etc.) }\end{array}$ & ILO/BFC & $\begin{array}{l}\text { Discuss roles and the } \\
\text { future of the garment } \\
\text { industry. } \\
\text { Discuss worker's safe- } \\
\text { ty and needs, stake- } \\
\text { holder's involvement } \\
\text { and partnerships, etc. }\end{array}$ & $\begin{array}{l}\text { International brands } \\
\text { and relevant national } \\
\text { stakeholders (including } \\
\text { MoLVT) }\end{array}$ & Annual \\
\hline $\begin{array}{l}\text { Providing for Health } \\
\text { Initiative (P4H) }\end{array}$ & $\begin{array}{l}\text { Social Health } \\
\text { Protection }\end{array}$ & $\begin{array}{l}\text { Rotating chair } \\
\text { among WHO, GIZ, } \\
\text { ILO and AFD }\end{array}$ & $\begin{array}{l}\text { Discuss coordination } \\
\text { efforts in providing } \\
\text { policy advice and } \\
\text { technical support for } \\
\text { Social Health Protec- } \\
\text { tion. }\end{array}$ & WHO, GIZ, ILO, and AFD & Adhoc basis \\
\hline $\begin{array}{l}\text { Tripartite Coordi- } \\
\text { nation Committee } \\
\text { (TCC)-HIV/AIDS and } \\
\text { drugs in the work- } \\
\text { place }\end{array}$ & HIV/AIDS & $\begin{array}{l}\text { Co-chaired by } \\
\text { MoLVT, Employers } \\
\text { and Union }\end{array}$ & $\begin{array}{l}\text { Prepare strategic } \\
\text { plan and activities } \\
\text { to support HIV/AIDS } \\
\text { prevention. }\end{array}$ & $\begin{array}{l}\text { Government (MoLVT), } \\
\text { Employers (GMAC } \\
\text { and CAMFEBA), Trade } \\
\text { Unions, Donors (UN- } \\
\text { AIDS, UNFPA, ILO, NGOs } \\
\text { (RHAC, KHEMARA), WH }\end{array}$ & $\begin{array}{l}\text { At least } 6 \\
\text { times a year }\end{array}$ \\
\hline $\begin{array}{l}\text { Technical Reference } \\
\text { Group (TRG) }\end{array}$ & $\begin{array}{l}\text { Cross-cutting } \\
\text { issues related to } \\
\text { health such as } \\
\text { referrals, work- } \\
\text { place programs, } \\
\text { midwives coordi- } \\
\text { nation }\end{array}$ & $\begin{array}{l}\text { Partnering to Sav- } \\
\text { ing Lives (PSL) }\end{array}$ & $\begin{array}{l}\text { Prepare for the } \\
\text { Technical Working } \\
\text { Group-Health meeting } \\
\text { (Chaired by Ministry of } \\
\text { Health). }\end{array}$ & $\begin{array}{l}\text { RMNH partners and } \\
\text { donors (WHO, UNICEF, } \\
\text { UNFPA, URC, GIZ, FHI } \\
\text { 360, MSIC, Save the } \\
\text { Children, CARE, DFAT) }\end{array}$ & Twice a year \\
\hline $\begin{array}{l}\text { Infirmary Working } \\
\text { Group }\end{array}$ & $\begin{array}{l}\text { Garment Factory } \\
\text { Infirmary Prakas } \\
\text { and Guidelines }\end{array}$ & UNFPA and USAID & $\begin{array}{l}\text { Update the existing } \\
\text { Prakas and develop } \\
\text { practical guidelines. }\end{array}$ & $\begin{array}{l}\text { UNFPA, USAID, Work- } \\
\text { erHealth, PSL (CARE, } \\
\text { Save the Children, } \\
\text { MSIC), RHAC, ILO/BFC }\end{array}$ & Adhoc basis \\
\hline
\end{tabular}




\section{E. ORGANIZATIONAL RELATIONSHIPS}

Any effort to promote stakeholder collaboration will need to work with and through organizations that have existing strong relationships with other influential stakeholders, and by providing interest, trust and incentive for engagement. This analysis examined relationships from three perspectives:

- Cross-sectoral relationships

- Within-sector relationships

- Unique relationships

\section{Cross-Sectoral Relationships}

Several stakeholders serve as the nexus of cross-sectoral relationships:

- MoLVT, GMAC, and ILO/BFC are the central players connected to the garment industry that interact with brands, government, labor, factories and, to varying degrees, NGOs.

- International agencies and bilateral donors also have many cross-cutting relationships, and have more direct involvement than industry stakeholders with NGOs, through project funding and support. They also have formal relationships with the RGC and ministries. As a key funder of health and family planning projects in the public health sector, USAID has good working relationships with $\mathrm{MoH}$ and MoLVT. This is also true for UNFPA, which advises the government on health related policies and strategies. AFD and DFAT have more experience with workplace health issues (insurance and workplace programs, respectively).

- Brands' primary relationships are with their supplier factories, but they also work with all sectors. Brands work with government, especially MoLVT, GMAC, and ILO/BFC, on labor policy and workplace issues. The NGOs identified for this analysis are focused on programmatic activities. Several brands individually have strong relationships with a few NGOs that implement or support workplace health programs for them.

\section{Within-Sector Relationships}

Organizations within sectors may work together and even collaborate as partners, although the examples are limited:

- NGOs in the health and development community know each other well, and in some cases have worked together on projects or as members of formal convenings. These projects have been donor-funded and include Partnering to Save Lives, in which CARE, Marie Stopes, and Save the Children are equal partners, and WorkerHealth, in which Population Council and MSIC are equal partners. The MoLVT Infirmary Guidelines policy process may strengthen the relationships of these NGOs (also including RHAC), as they jointly consider policy changes.

- International agencies collaborate to varying degrees on policies and programs of the RGC. USAID and UNFPA work together on reproductive health and family planning policies with the government. Agencies participate often on policy consultations and initiatives, such as the Social Health Protection program and framework, which involves the Word Bank, ILO, USAID, GIZ, ILO, and others. There has been limited apparent collaboration between agencies on specific health activities related to factories and workplace health policy.

- The leading industry associations, GMAC and the Cambodian Federation of Employers and Business Associations (CAMFEBA), have strong institutional ties with each other and share policy positions, as they represent industry and employers. As membership organizations, they have direct access to and working relationships with factory management.

\section{Unique Relationships}

Several organizations have developed unique relationships or access that should be considered:

- GMAC and NGOs have strived to work together on workplace health and safety activities. One example of a successful and long standing collaboration is that of Care and GMAC on the development of the Strengthening Activities for Factory Education (SAFE) Working Group.

- The partnership between SC and ACF and the unions is unique. The Solidarity Center has strong relationships with certain independent unions to build their capacity and assist in challenging violations of labor law. The ACF, which is viewed as impartial and neutral through its support of the Arbitration Council, also works with unions on dispute resolution.

- Several NGOs have formed partnerships with brands to implement workplace health and well-being programs in Cambodia: CARE, Marie Stopes, RHAC, and BSR HERproject. Through these activities, they also have developed relationships with the factories where interventions took place.

- Brands have direct business relationships with factory owners in headquarters outside of Cambodia. A brand's regional or headquarters staff interact directly with these owners for Cambodia and other country business, in addition to the brand's lo- 
cal staff dealing one-one-one with each supplier factory. Many brands differentiate between their strategic suppliers, which produce most of their garments and receive brand support for capacity building and other programs, and non-strategic suppliers.

These organizational relationships can be the foundation for collaboration on worker health policy and programs.

\section{CHALLENGES}

Stakeholder interviews and the desk review of industry documents identified the following major challenges:

Building a working relationship with industry associations and factories around policy dialogue and activities. Most industry associations and factories view worker health as having significant business costs, and see recent policy changes as challenging to their interests. For most factories, the decision-makers are based in corporate headquarters outside of Cambodia, and local managers may not feel empowered to be part of the policy dialogue.

Engaging labor unions and worker representatives to ensure worker voice and input. The current labor environment is particularly complex, and unions have competing agendas and alliances. This makes it difficult to engage them and to identify those that best represent workers' interests.

Collaborating with health-focused NGOs in a competitive environment. Several health NGOs have significant experience with workplace health pro- grams and have similar activities in garment factories, and each has an interest in maintaining separate brand and industry relationships. NGOs have sometimes struggled in their work with brands, as expectations are high but resources are relatively limited.

Creating space for collaboration in the face of competing demands for stakeholders' attention. The garment industry is addressing many issues, including wages, union formation, strikes, fainting, workplace and transportation safety. Newer, emerging issues have difficulty gaining entry into the discussions as priorities.

Coordinating donors involved in the garment industry around a garment worker health agenda. Each donor is interested in worker health, but with different priorities. Cooperation among donors is more likely at the policy and national levels than at the factory or brands level.

Supporting inter-ministerial coordination. Each Ministry has its own priorities and mandate, and coordination has always been a challenge. The government's structure, bureaucracy and different work priorities can hinder coordination within and across the ministries.

Building recognition of health - and reproductive health and family planning - as a priority issue for industry, brands, and labor. While health and reproductive health are acknowledged as important to women, other health and non-health issues are considered more important to workers well-being and industry stability such as industrial relations.

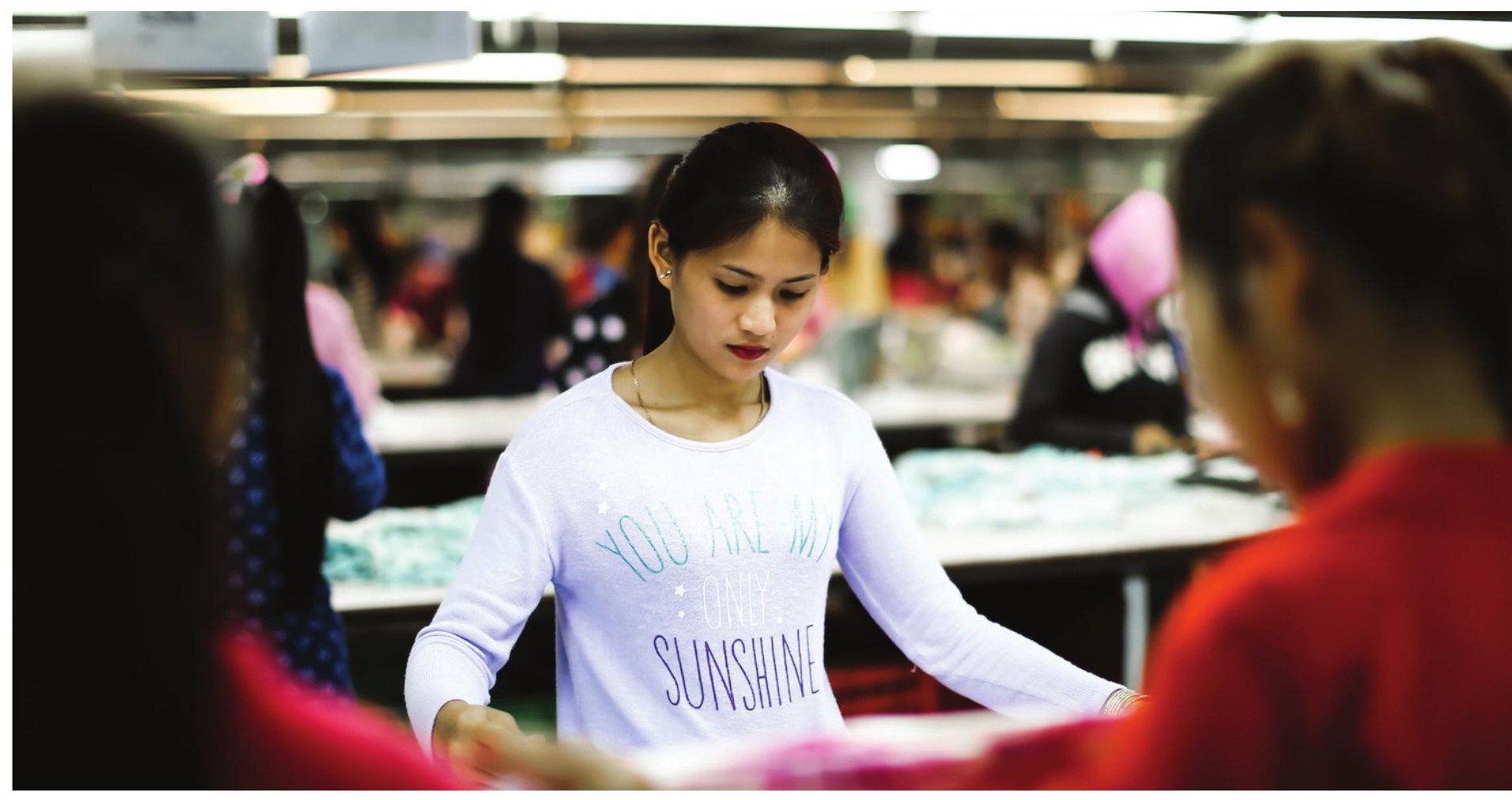




\section{RECOMMENDED ACTIONS}

Stakeholders have limited time and often limited resources, in an environment with many competing demands and many divisive and difficult issues to address. Efforts to build collaborative activities around female work health must work around these challenges. This analysis identified several strategies to foster collaboration:

\section{RECOMMENDATION 1}

Build on the engagement with key ministries and stakeholders to establish a multi-stakeholder platform to advance national and workplace related policies.

The core structural principle of the Working Group (see Table 3) is that no single organization owns or controls the process. The infirmary working group was formed as a good example with leadership shared by USAID and UNFPA; and the secretariat, by WorkerHealth, each with different donors and multiple NGO partners.

The Working Group will support the policy dialogue process by organizing broader stakeholder consultations that feed into government deliberations. This process

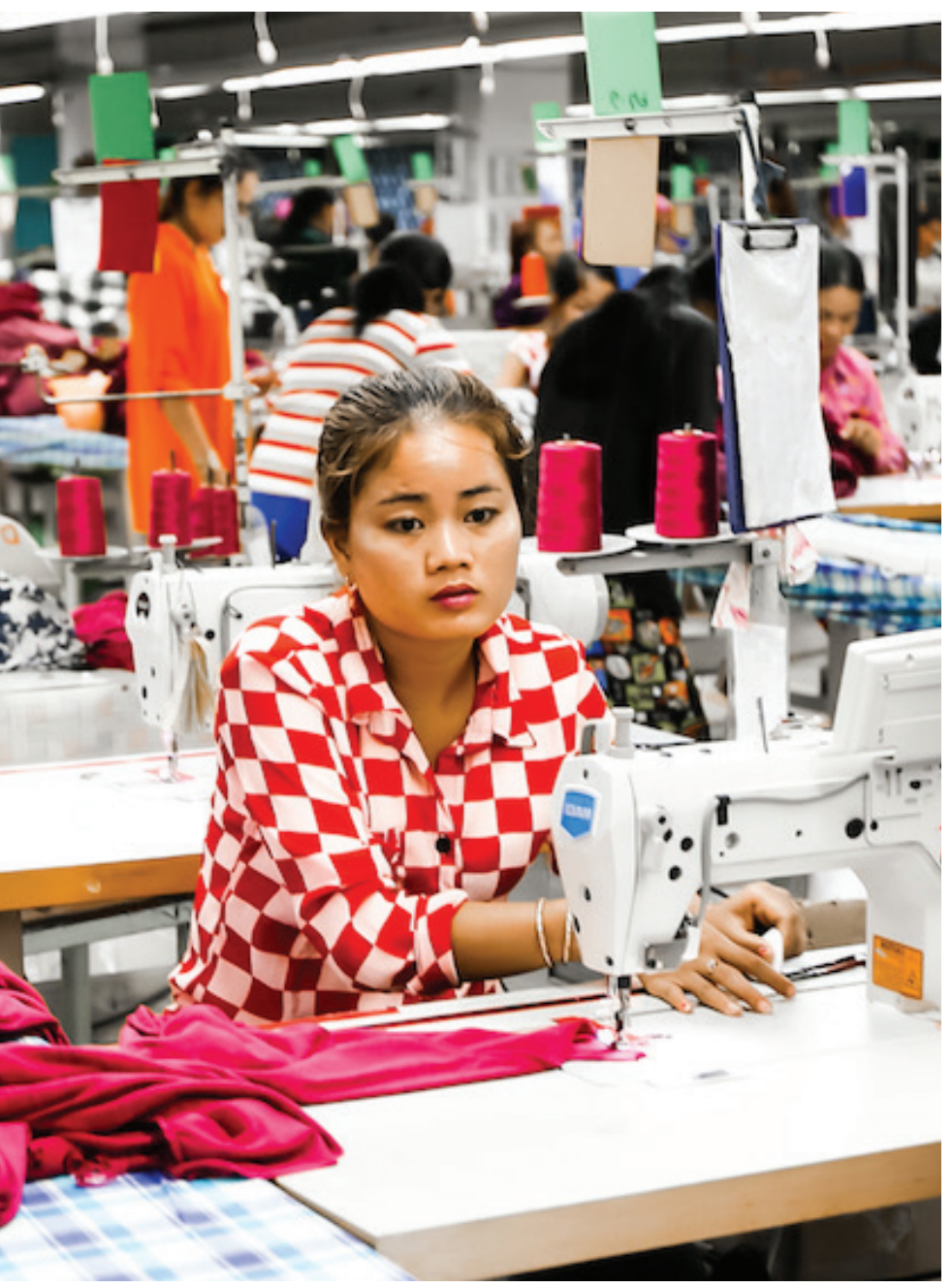

can be the foundation to the more formal establishment of platform for dialogue on women's worker health in factories and collaboration.

\section{RECOMMENDATION 2}

Leverage USAID and UNFPA's convening power to engage key international agencies and donors, promote collaborative activities, and build on the Working Group process.

Multiple international agencies - USAID, UNFPA, ILO, GIZ, AFD and DFAT - have projects focused on the garment industry. There is a great need for coordination and collaboration, as the activities of each agency will make unique demands on industry, brands, NGOs and government. USAID and UNFPA can play an essential role in facilitating and promoting collaboration through their extensive relationships with government ministries, NGOs and donors. USAID, with UNFPA, can help find common ground with other donors around worker health including working jointly on forums and other convenings.

\section{RECOMMENDATION 3}

Leverage brand relationships with business associations, NGO partners, and supplier factories to advance policy dialogue and programmatic linkages.

Brands are connected to many different stakeholders and can be key to helping stakeholders build relationships and to promoting collaboration. They work closely with GMAC, some health NGOs, ministries and factory ownership groups, and are in a unique position to bring organizations together.

\section{RECOMMENDATION 4}

\section{Engage workers through}

organizations that interact and have relationships with workers, including ILO/Better Factories Cambodia and the Arbitration Council Foundation.

Worker input is very important to changes that affect their lives, and workers are the most likely to be left out of policy dialogues on worker health. Organizations like BFC ILO and others mentioned above that engage with workers can play an important role in ensuring workers have a voice on workplace and community health interventions and policies. 


\section{RECOMMENDATION 5}

Recognize the rich experience, specific capacities, and unique relationships of key NGOs.

It is important to recognize the expertise and experience of all stakeholders in any collaborative efforts, whether through an emerging platform of the Working Group or other collaborative activities. Shared recognition and shared credit are key building blocks for ongoing collaboration.

Many NGOs have overlapping areas of interest and complementary programs and capacities. Marie Stopes and RHAC have extensive experience working in factories and run quality clinics that provide reproductive health and family planning services, among other services. Save the Children is an expert in maternal health and nutrition. Non-health NGOs may be well-positioned for collaboration on worker heath.

\section{RECOMMENDATION 6}

\section{Engage existing forums and} convenings for policy dialogue, as a way to share stakeholders' experiences and disseminate knowledge and information.

As organizations have limited time and resources, it is important to promote the use of existing forums for policy dialogue and sharing. It is also important to leverage opportunities for NGOs, labor, and other stakeholders to share and receive information and coordinate in ways that support their individual interests and joint goals.

\section{RECOMMENDATION 7}

\section{Promote, develop, and disseminate} knowledge products and evidence that can build support for collaboration and better policies and practices for worker health.

Industry stakeholders need to be aware of good practices related to worker health and the evidence demonstrating the connection between worker health, workplace practices that promote health, and business benefits. Economic concerns will always be a priority. The more stakeholders understand the potential business benefits of addressing the reproductive health and broader health needs of workers, the easier engagement with industry will be. Furthermore, research in other industries has shown that local companies are often unaware of better practices used by competitors in their area or region.

\section{CONCLUSION}

Collaboration and collective action on worker health will require key organizations to work together, leverage relationships and influence other stakeholders to take part. Given the competitive environment, no single organization can be the owner or driver of such a process. It requires collaboration and joint ownership by multiple stakeholders. These recommendations are a starting point for addressing the challenges of working in a crowded policy landscape and an industry under much pressure.

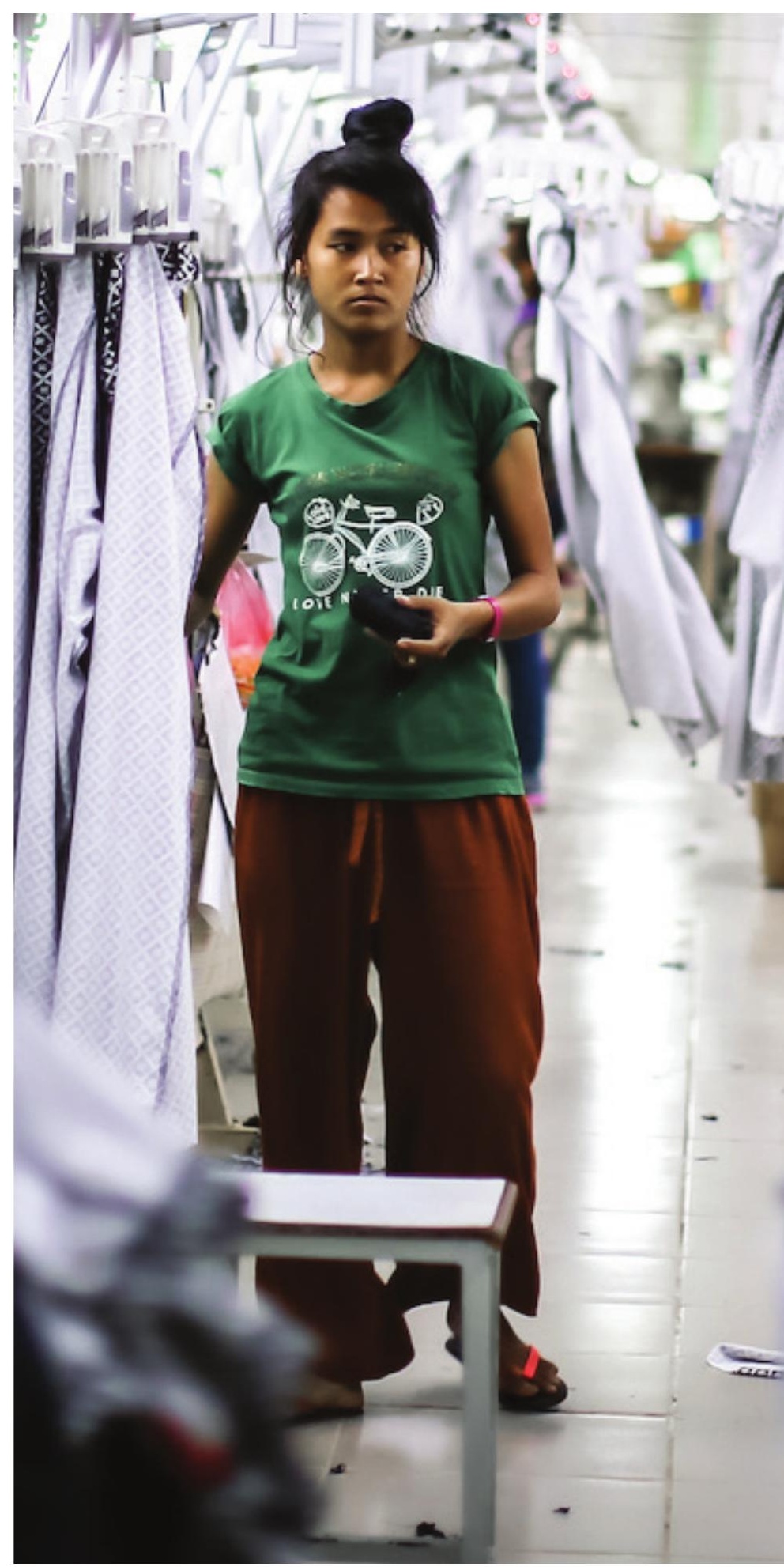




\section{ACKNOWLEDGEMENTS}

Our special thanks go to key informants and contributors who provided information for this analysis, including the Ministry of Labour and Vocational Training and individual organizations working on improving the health and well-being of garment factory workers in Cambodia. We are also thankful to the United States Agency for International Development (USAID) in Cambodia for their generous support for the Cambodia Worker Health Coalition (WorkerHealth) Project, under which this analysis was conducted.

\section{THE EVIDENCE PROJECT}

Population Council

\#12 Eo, St. 41, Sangkat Tonle

Bassac

Khan Chamkar Morn

Phnom Penh, Cambodia

+85510330184

evidenceproject@popcouncil.org

CONTRIBUTORS Bunmey Yat

Carolyn Rodehau David Wofford

Ashish Bajracharya Karen Hardee

Kate Gilles

Anneka Van Scoyoc

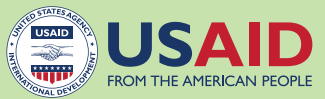

The Evidence Project is made possible by the generous support of the American people through the United States Agency for International Development (USAID) under the terms of cooperative agreement no. AID-OAA-A-13-00087. The contents of this document are the sole responsibility of the Evidence Project and Population Council and do not necessarily reflect the views of USAID or the United States Government.

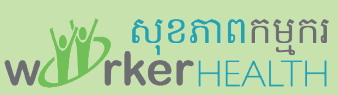

WorkerHealth is a joint initiative managed by Marie Stopes International and the Population Council's Evidence Project. Marie Stopes International implements the Support for International Family Planning and Health Organizations 2: Sustainable Networks (SIFPO2) program, which is funded by the US Agency for International Development (USAID), under Cooperative Agreement No. AID-OAA-A-14-000036.

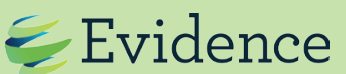

The Evidence Project uses implementation science-the strategic generation, translation, and use of evidence-to strengthen and scale up family planning and reproductive health programs to reduce unintended pregnancies worldwide. The Evidence Project is led by the Population Council in partnership with INDEPTH Network, International Planned Parenthood Federation, PATH, Population Reference Bureau, and a University Research Network.

Meridian Group Intiernotional, Inc.

Meridian Group International, Inc. is a woman-owned, small business that works with the private and public sectors to create innovative programs and partnerships that benefit both business and society. Meridian Group International, Inc. is a partner of the Evidence Project and the Cambodia Worker Health Coalition.

Suggested Citation: Yat, Bunmey, Carolyn Rodehau, and David Wofford. 2017. "Workplace Health and the Garment Sector in Cambodia" Policy Brief. Washington DC and Phnom Penh, Cambodia: Population Council, The Evidence Project.

(C) 2017 The Population Council, Inc.

Photo credit for all photos: (c) 2016 Ashish Bajracharya 